\title{
Candida bromeliacearum sp. nov. and Candida ubatubensis sp. nov., two yeast species isolated from the water tanks of Canistropsis seidelii (Bromeliaceae)
}

\author{
Correspondence \\ Carla C. C. Ruivo \\ carlaccr@yahoo.com.br
}

\author{
Carla C. C. Ruivo, ${ }^{1}$ Marc-André Lachance, ${ }^{2}$ Carlos A. Rosa, ${ }^{3}$ \\ Maurício Bacci $\mathrm{Jr}^{1}$ and Fernando C. Pagnocca ${ }^{1}$ \\ ${ }^{1}$ Centro de Estudos de Insetos Sociais e Departamento de Bioquímica e Microbiologia, \\ Universidade Estadual Paulista - Unesp, CP 199, Rio Claro, SP, 13506-900, Brazil \\ ${ }^{2}$ Department of Biology, University of Western Ontario, London, Ontario, Canada N6A 5 B7 \\ ${ }^{3}$ Departamento de Microbiologia - ICB, CP 486, Universidade Federal de Minas Gerais, \\ Belo Horizonte, MG, 31270-901, Brazil
}

\begin{abstract}
Strains belonging to two novel yeast species, Candida bromeliacearum and Candida ubatubensis, were isolated from the bromeliad tank of Canistropsis seidelii (Bromeliaceae) in a sandy coastal plain (restinga) ecosystem site in an Atlantic rainforest of south-eastern Brazil. These species were genetically distinct from all other currently accepted ascomycetous yeasts, based on sequence divergence in the D1/D2 domains of the large-subunit rDNA and in the small-subunit rDNA. The species occupy basal positions in the Metschnikowiaceae clade. The type strains are Candida bromeliacearum UNESP 00-103 ${ }^{\top}\left(=\mathrm{CBS}_{10002^{\top}}=\mathrm{NRRL}\right.$ Y $\left.-27811^{\top}\right)$ and Candida ubatubensis UNESP 01-247R ${ }^{\top}\left(=\right.$ CBS $10003^{\top}=$ NRRL Y-27812 $\left.{ }^{\top}\right)$.
\end{abstract}

The Bromeliaceae constitutes a large plant family that is endemic to the neotropics and exhibits a high species richness in south-eastern Brazil. The plants are mostly epiphytes that form phytotelms or water tanks. The water accumulated in the tanks of some species can function as a microhabitat for aquatic organisms, including plants, animals and micro-organisms (Hagler et al., 1993; Araújo et al., 1998). This water has a high nutrient concentration, creating an adequate environment for the development of a complex microbial community (Benzing et al., 1972). During a survey of yeasts associated with plants in tropical ecosystems of south-eastern Brazil, strains belonging to two novel yeast species were isolated from the water tanks of the bromeliad Canistropsis seidelii. The sequences of the D1/D2 domains of the large-subunit (LSU) rDNA and the smallsubunit (SSU) rDNA showed that these isolates were genetically distinct from all currently accepted ascomycetous yeasts. Therefore, the novel yeast species Candida bromeliacearum sp. nov. and Candida ubatubensis sp. nov. are described.

Published online ahead of print on 1 April 2005 as DOI 10.1099/ ijs.0.63698-0.

\footnotetext{
Abbreviations: LSU, large subunit; SSU, small subunit.

The GenBank/EMBL/DDBJ accession numbers for the large-subunit and small-subunit rRNA gene sequences for strain UNESP 00-103 ${ }^{\top}$ are AY695394 and AY695396, respectively, and AY695395 and AY695397, respectively, for strain UNESP 01-247R'.
}

\section{Yeast isolation and characterization}

Three strains each of Candida bromeliacearum and Candida ubatubensis were isolated from water tanks of the bromeliad Canistropis seidelii in the Picinguaba site in the 'Serra do Mar' State Park, in São Paulo State, Brazil ( $23^{\circ} 22^{\prime}$ S $44^{\circ} 48^{\prime}$ W). This State Park contains one of the largest continuous areas of the remaining Brazilian Atlantic Forest in eastern São Paulo State, and is located $230 \mathrm{~km}$ from the city of São Paulo. For the isolation of strains belonging to Candida bromeliacearum, the water tanks of six plants were collected during spring (September) 2000, whereas the strains belonging to Candida ubatubensis were isolated during summer (February) 2001, when the water reservoirs of five plants were examined. The plants occurred over a large area of the forest.

The water collected was stirred with a sterile loop and streaked in triplicate on YM agar ( $1 \%$ glucose, $0.5 \%$ peptone, $0.3 \%$ malt extract, $0.3 \%$ yeast extract, $2 \%$ agar) containing $100 \mathrm{mg}$ chloramphenicol $1^{-1}$ (Trindade et al., 2002). The plates were incubated at $25^{\circ} \mathrm{C}$ for $3-5$ days, and one of each distinct morphotype was isolated and maintained on YM agar slants at $6-8{ }^{\circ} \mathrm{C}$ and at $-80^{\circ} \mathrm{C}$. The yeasts were characterized by using standard methods (Yarrow, 1998), and their identification was carried out using the keys of Kurtzman \& Fell (1998) and the CD-ROM Yeasts of the World (Boekhout et al., 2002). 


\section{DNA sequence analysis}

Yeast DNA was extracted and purified according to a protocol recommended for the Genomic Prep. Cells and Tissue DNA isolation kit (Amersham Pharmacia Biotech). The divergent D1/D2 domains of the LSU rDNA were amplified with primers NL1 and NL4 (O'Donnell, 1993). Each PCR was performed with the Ready-To-Go kit (Amersham Pharmacia Biotech) using $1.5 \mu$ l solution containing approximately $100 \mathrm{ng}$ DNA, $1 \cdot 6 \mu \mathrm{l} \mathrm{NL1}$ primer, $1 \cdot 1 \mu \mathrm{l}$ NL4 primer (6 pmol each) and $17 \cdot 8 \mu \mathrm{l}$ Milli-Q water. The sequence products were resolved in an ABI Prism 377 DNA sequencer (Applied Biosystems) at the Centro de Estudos de Insetos Sociais - UNESP, Rio Claro, São Paulo, Brazil. Alternatively, the DNA was amplified directly from whole cells and sequenced as described by Lachance et al. (1999). The SSU rDNA was amplified by using this method, with primers SSU1f ( $3^{\prime}$-CTGGTTGATCCTGCCAGTAGTCATA-3') and SSU2r (5'-ATGATCCTTCCGCAGGTTCAC$\left.3^{\prime}\right)$. The amplification products were purified on Qiagen columns and sequenced using the same primers as for the amplification, plus the primers SSU3f $\left(5^{\prime}\right.$-TGGAGGGCAAGTCTGGTGCCA-3') and SSU4r (5'-AACTAAGAACGGCCATGCACCA-3'). Sequencing was performed with an ABI automated sequencer at the Robarts Research Institute, London, Ontario, Canada. Sequence alignment and tree construction were done with the program DNAMAN 4.1 (Lynnon Biosoft).

\section{Species delineation, classification and ecology}

The physiological characteristics of the novel species were typical of those of other species in the Metschnikowiaceae clade, although the absence of growth on galactose and the weak utilization of trehalose observed for Candida bromeliacearum are not common. The isolates of Candida bromeliacearum and Candida ubatubensis were examined after growth on most common sporulation media ( $5 \%$ malt extract agar, cornmeal agar, Fowell acetate agar and dilute V8 agar), but asci were not formed. Mixed pairs showed no signs of conjugation, suggesting that these species occur in nature in the asexual form.

Assignment of the isolates to novel species was based principally on DNA sequence analyses. The D1/D2 LSU rDNA sequences (514 and 509 bases, respectively, for Candida ubatubensis and Candida bromeliacearum) of both species were so divergent that a credible placement near any particular species in the Metschnikowia clade was not possible. For this reason, the SSU rDNA sequences (1698 and 1662 bases, respectively, for Candida ubatubensis and Candida bromeliacearum) were determined and included in the analysis (Fig. 1). Trees obtained separately based on the two DNA regions were mostly, but not entirely, congruent. Removal of gapped regions did not alter the trees significantly. Although Candida bromeliacearum is shown as a sister species to Candida haemulonii, the species are positioned at the ends of relatively long internodes and are joined together by a much shorter internode. As the SSU rDNA sequence for 'Candida haemulonii type II', an undescribed variant of the species, was not available, this variant was not included in the tree. However, an analysis of the D1/D2 region showed that Candida bromeliacearum is more or less equidistant from the two sister species currently assigned to Candida haemulonii.

One could therefore suspect that the addition of yet undiscovered taxa to the analysis may well cause a different branching order to appear, in spite of the high bootstrap values. As for Candida ubatubensis, a specific placement within the clade would be purely speculative.

Because all of the isolates of these species were obtained from the same site, it cannot be assumed that they were

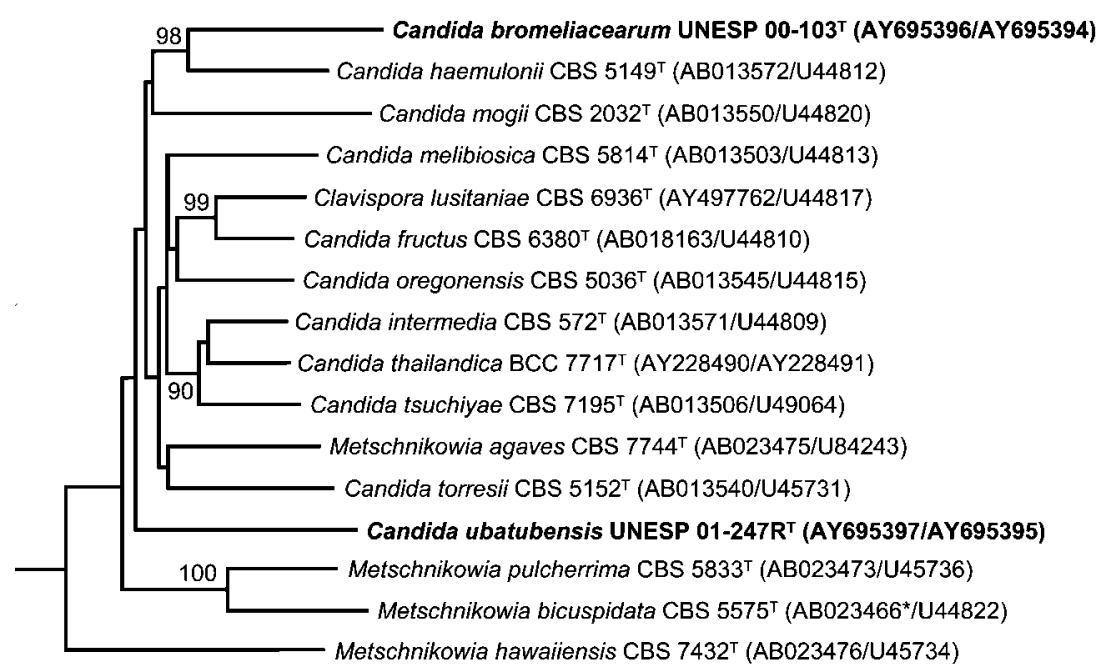

Fig. 1. Neighbour-joining phylogram showing the position of Candida bromeliacearum and Candida ubatubensis among related species. The tree was constructed from concatenated sequences of the SSU rDNA and the D1/D2 region of the LSU rDNA. The species included were chosen to represent the various subclades of the Metschnikowiaceae clade, subject to availability of both sequences. Bootstrap values from 1000 pseudoreplicates are shown for values above $70 \%$ only. The tree was rooted by inclusion of the sequences for Schizosaccharomyces pombe as an outgroup (not shown). *, The GenBank accession number given pertains to strain IFO 1408 . 
directly associated with the bromeliad water tank, which has a dynamic influx of a diversity of arthropod and amphibian visitors. As only three isolates of Candida bromeliacearum and three of Candida ubatubensis were recovered from a collection that comprised 29 isolates, the role of these species in the bromeliad yeast community remains obscure. In a similar approach, Hagler et al. (1993) and Araújo et al. (1998) described the yeast communities of the water tanks of the bromeliad species Quesnelia quesneliana, Quesnelia arvensis, Neoregelia cruenta, Nidularium procedurum, Aechmea nudicaulis and Vriesia procera occurring in mangrove and sand dune ecosystems. The yeast communities found in those reports and in our study are quite different, as they share only Candida famata and Candida intermedia, two widespread, generalistic species.

\section{Latin diagnosis of Candida bromeliacearum Ruivo, Pagnocca, Lachance et Rosa sp. nov.}

In medio liquido post dies tres ad $25^{\circ} \mathrm{C}$, cellulae ellipsoideae aut elongatae, singulae aut in catenis brevis $(3-5 \times 4-6 \mu \mathrm{m})$. Cultura in agaro extracta malti et levidinis continente post dies 4 ad $25^{\circ} \mathrm{C}$, albida cremae et butyrosa. In agaro farinae Zea mays post dies 14 mycelium nec pseudomycelium non formantur. Asci non formantur. Glucosum fermentatur. Glucosum, sucrosum, trehalosum (exigue), maltosum, melezitosum, methyl $\alpha$-D-glucosidium, cellobiosum, salicinum, L-sorbosum, D-xylosum, ethanolum, glycerolum (variabile), erythritolum (variabile), ribitolum, xylitolum, mannitolum, glucitolum, acidum citricum (exigue et variabile), acidum gluconicum (variabile), glucono- $\delta$-lactonum, 2-ketogluconatum, D-glucosaminum, $\mathrm{N}$-acetylglucosaminum, et $\mathrm{n}$-hexadecanum (lente) assimilantur. Non assimilantur inulinum, raffinosum, melibiosum, galactosum, lactosum, amylum solubile, L-rhamnosum, L-arabinosum, D-arabinosum, D-ribosum, methanolum, galactitolum, myo-inositolum, acidum lacticum, acidum succinicum, 5-ketogluconatum, Larabinitolum nec acidum glucuronicum. Lysinum, ethylaminum et cadaverinum assimilantur at non natrium nitrosum nec natrium nitricum. Augmentum in $35^{\circ} \mathrm{C}$, non crescit in $37^{\circ} \mathrm{C}$. Ureum non finditur. Diazonium caeruleum B negativum. Materia amyloidea non formantur. Crescit (lente) in agaro extrato fermenti confecto 50 partes glucosi per centum. Non crescit in medio $100 \mu \mathrm{M} \mathrm{ml}^{-1}$ cycloeximido addito. Habitat aquam in Canistropsis seidelii (L.B. SM.) Leme. (Bromeliaceae). Typus stirps UNESP 00-103 ${ }^{\mathrm{T}}$. In collectione zymotica Centraalbureau voor Schimmelcultures, Trajectum ad Rhenum, sub no. CBS $10002^{\mathrm{T}}$, typus stirps deposita est.

\section{Description of Candida bromeliacearum Ruivo, Pagnocca, Lachance \& Rosa sp. nov.}

Candida bromeliacearum (bro.me.li.a.ce.a' rum. N.L. gen. $\mathrm{n}$. bromeliacearum of Bromeliaceae, referring to the plant from which the yeast was isolated).

In yeast extract $(0.5 \%)$ glucose $(2 \%)$ broth after 3 days at $25^{\circ} \mathrm{C}$, the cells are ellipsoidal to elongate $(3-5 \times 4-6 \mu \mathrm{m})$, and occur singly, in budding pairs or in short chains. Buds are produced multilaterally (Fig. 2a). On YM agar after 4 days at $25^{\circ} \mathrm{C}$, the colonies are white to cream, smooth and butyrous. After 2 weeks in Dalmau plate culture on cornmeal agar, pseudomycelium or true mycelium is not formed. Asci are not formed on common sporulation media. Glucose fermentation is complete after 2-5 days. Assimilation of carbon compounds: glucose, sucrose, trehalose (weak), maltose, melezitose, methyl $\alpha$-D-glucoside, cellobiose, salicin, L-sorbose, D-xylose, ethanol, glycerol (variable), erythritol (variable), ribitol, xylitol, D-mannitol, D-glucitol, citric acid (weak and variable), D-gluconate (variable), glucono- $\delta$-lactone, 2-ketogluconic acid, glucosamine, $\mathrm{N}$-acetylglucosamine and n-hexadecane (slow) are assimilated. No growth occurs on inulin, raffinose, melibiose, galactose, lactose, starch, L-rhamnose, L-arabinose, D-arabinose, D-ribose, methanol, L-arabinitol, galactitol, myo-inositol, lactic acid, succinic acid, 5-ketogluconic acid, saccharate or D-glucuronate. The following nitrogen compounds are assimilated: cadaverine, lysine and ethylamine; nitrate and nitrite are negative. Growth at $35^{\circ} \mathrm{C}$ is positive and negative at $37^{\circ} \mathrm{C}$. Acid formation on chalk agar is positive. Urease activity and Diazonium blue $\mathrm{B}$ reaction are negative. Production of amyloid compounds is negative.
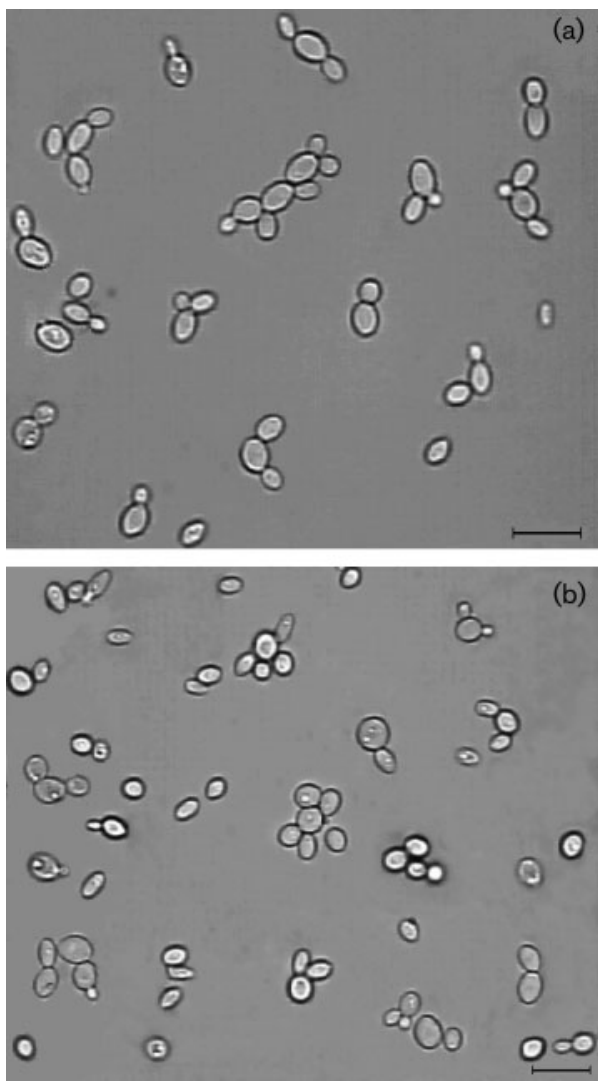

Fig. 2. Photomicrographs of cells of Candida bromeliacearum strain UNESP $00-103^{\top}$ (a) and Candida ubatubensis strain UNESP $01-247 R^{\top}$ (b) in yeast extract, glucose broth after 3 days at $25^{\circ} \mathrm{C}$. Bars, $10 \mu \mathrm{m}$. 
Growth on $50 \%$ glucose/yeast extract agar is slow. Growth on $\mathrm{YM}$ agar with $10 \% \mathrm{NaCl}$ is positive. Growth in the presence of $1 \%$ acetic acid is negative. Growth in the presence of 0.1 and $0.01 \%$ cycloheximide is negative.

The type strain, UNESP $00-103^{\mathrm{T}}$, has been deposited in the collection of the Yeast Division of the Centraalbureau voor Schimmelcultures, Utrecht, The Netherlands, as strain CBS $10002^{\mathrm{T}}\left(=\right.$ NRRL Y-27811 $\left.{ }^{\mathrm{T}}\right)$.

\section{Latin diagnosis of Candida ubatubensis Ruivo, Pagnocca, Lachance et Rosa sp. nov.}

In medio liquido post dies tres ad $25^{\circ} \mathrm{C}$, cellulae globosae aut ovoidae, singulae aut binae $(3-4 \cdot 5 \times 4-6 \mu \mathrm{m})$. Cultura in agaro extracta malti et levidinis continente post 4 dies ad $25^{\circ} \mathrm{C}$, albida cremae et butyrosa. In agaro farinae Zea mays post dies 14 mycelium nec pseudomycelium non formantur. Asci non formantur. Glucosum fermentatur. Glucosum, sucrosum, galactosum, trehalosum, maltosum, melezitosum, methyl $\alpha$-D-glucosidium, cellobiosum, salicinum, L-sorbosum, L-rhamnosum (exigue), D-xylosum, D-ribosum, ethanolum, glycerolum, erythritolum, ribitolum, xylitolum, L-arabinitolum, mannitolum, glucitolum, acidum gluconicum, glucono- $\delta$-lactonum (variabile), $\mathrm{N}$ acetylglucosaminum et $\mathrm{n}$-hexadecanum assimilantur. Non assimilantur inulinum, raffinosum, melibiosum, lactosum, amylum solubile, L-arabinosum, D-arabinosum, methanolum, galactitolum, myo-inositolum, acidum lacticum, acidum succinicum, acidum citricum, 2-ketogluconatum, 5ketogluconatum nec D-glucosaminum. Lysinum, ethylaminum et cadaverinum assimilantur at non natrium nitrosum nec natrium nitricum. Augmentum in $35^{\circ} \mathrm{C}$, non crescit in $37^{\circ}$ C. Ureum non finditur. Diazonium caeruleum B negativum. Materia amyloidea non formantur. Non crescit in agaro extrato fermenti confecto 50 partes glucosi per centum. Non crescit in medio $100 \mu \mathrm{M} \mathrm{ml}^{-1}$ cycloeximido addito. Habitat aqua in Canistropsis seidelii (Bromeliaceae). Typus stirps UNESP $01-247 \mathrm{R}^{\mathrm{T}}$. In collectione zymotica Centraalbureau voor Schimmelcultures, Trajectum ad Rhenum, sub no. CBS $10003^{\mathrm{T}}$, typus stirps deposita est.

\section{Description of Candida ubatubensis Ruivo, Pagnocca, Lachance \& Rosa sp. nov.}

Candida ubatubensis (u.ba.tu.ben'sis. N.L. nom. fem. adj. ubatubensis of Ubatuba, referring to a town near which the yeast was isolated).

In yeast extract $(0 \cdot 5 \%)$ glucose $(2 \%)$ broth after 3 days at $25^{\circ} \mathrm{C}$, the cells are spheroidal to ovoid $(3-4 \cdot 5 \times 4-6 \mu \mathrm{m})$, and occur singly or in budding pairs. Buds are produced multilaterally (Fig. 2b). On YM agar after 4 days at $25^{\circ} \mathrm{C}$, the colonies are white to cream, smooth and butyrous. After 2 weeks in Dalmau plate culture on cornmeal agar, pseudomycelium or true mycelium is not formed. Asci are not formed on common sporulation media. Glucose fermentation is complete after $2-5$ days. Assimilation of carbon compounds: glucose, galactose, sucrose, trehalose, maltose, melezitose, methyl $\alpha$-D-glucoside, cellobiose, salicin, L-sorbose, L-rhamnose (weak), D-xylose, D-ribose, ethanol, glycerol, erythritol, ribitol, xylitol, L-arabinitol, D-mannitol, D-glucitol, D-gluconate, glucono- $\delta$-lactone (variable), $\mathrm{N}$-acetylglucosamine and $\mathrm{n}$-hexadecane are assimilated. No growth occurs on inulin, raffinose, melibiose, lactose, starch, L-arabinose, D-arabinose, methanol, galactitol, myo-inositol, lactic acid, succinic acid, citric acid, 2-ketogluconic acid, 5-ketogluconic acid or glucosamine. The following nitrogen compounds are assimilated: lysine, ethylamine and cadaverine; nitrate and nitrite are negative. Growth at $35^{\circ} \mathrm{C}$ is positive and negative at $37^{\circ} \mathrm{C}$. Urease activity and Diazonium blue $\mathrm{B}$ reaction are negative. Production of amyloid compounds is negative. Growth on $50 \%$ glucose/yeast extract agar is negative. Growth on YM agar with $10 \% \mathrm{NaCl}$ is positive. Growth in the presence of $1 \%$ acetic acid is negative. Growth in the presence of $0 \cdot 1$ and $0 \cdot 01 \%$ cycloheximide is negative.

The type strain, UNESP $01-247 \mathrm{R}^{\mathrm{T}}$, has been deposited in the collection of the Yeast Division of the Centraalbureau voor Schimmelcultures, Utrecht, The Netherlands, as strain CBS $10003^{\mathrm{T}}\left(=\right.$ NRRL Y-27812 $\left.{ }^{\mathrm{T}}\right)$.

\section{Acknowledgements}

The authors acknowledge the UNESP-CEIS for supporting this research project, and the Secretaria de Meio Ambiente (São Paulo State, Brazil) for permission to collect in the Picinguaba Nucleus at the 'Serra do Mar' State Park (Process. SMA: 42.364/99). We thank Dr Marco Antônio de Assis (Universidade Estadual Paulista - UNESP) for assistance in the collection and identification of plant species. We acknowledge financial support from the Coordenação de Aperfeiçoamento de Pessoal de Nível Superior (CAPES), the Conselho Nacional de Desenvolvimento Científico e Tecnológico $(\mathrm{CNPq})$ and the Natural Science and Engineering Research Council of Canada.

\section{References}

Araújo, F. V., Medeiros, R. J., Mendonça-Hagler, L. C. \& Hagler, A. N. (1998). A preliminary note on yeast communities of bromeliad-tank waters of Rio de Janeiro, Brazil. Rev Microbiol 29, 118-121.

Benzing, D. H., Derr, J. A. \& Titus, J. E. (1972). The water chemistry of microcosms associated with the bromeliad Aachmea bracteata. Am Midl Nat 87, 60-70.

Boekhout, T., Robert, V., Smith, M. Th. \& 9 other authors (2002). Yeasts of the World. Morphology, Physiology, Sequences and Identification. Biodiversity Center of ETI, Multimedia Interactive Software. Windows version 2.0. Heidelberg: Springer.

Hagler, A. N., Rosa, C. A., Morais, P. B., Mendonça-Hagler, L. C., Franco, G. M., Araújo, F. V. \& Soares, C. A. (1993). Yeasts and coliform bacteria of water accumulated in bromeliads of mangrove and sand dune ecosystems of southeast Brazil. Can J Microbiol 39, 973-977.

Kurtzman, C. P. \& Fell, J. W. (editors) (1998). The Yeasts $-a$ Taxonomic Study, 4th edn. Amsterdam: Elsevier.

Lachance, M. A., Bowles, J. M., Starmer, W. T. \& Barker, J. S. F. (1999). Kodamaea kakaduensis and Candida tolerans, two new 
ascomycetous yeast species from Australian Hibiscus flowers. Can J Microbiol 45, 172-177.

O'Donnell, K. (1993). Fusarium and its near relatives. In The Fungal Holomorph: Mitotic, Meiotic and Pleomorphic Speciation in Fungal Systematics, pp. 225-233. Edited by D. R. Reynolds \& J. W. Taylor. Wallingford, UK: CAB International.
Trindade, R. C., Resende, M. A., Silva, C. M. \& Rosa, C. A. (2002). Yeasts associated with fresh and frozen pulps of Brazilian tropical fruits. Syst Appl Microbiol 25, 294-300.

Yarrow, D. (1998). Methods for the isolation and identification of yeasts. In The Yeasts - a Taxonomic Study, 4th edn, pp. 77-100. Edited by C. P. Kurtzman \& J. W. Fell. Amsterdam: Elsevier. 